\title{
AN EXPOSITORY STUDY OF THE ISLAMIC APPROACH IN THE JURISPRUDENCE OF RIGHT TO HEALTHFUL ENVIRONMENT
}

\author{
Abdulkadir Bolaji Abdulkadir*
}

\begin{abstract}
The Stockholm Conference of 1972 marked the emergence of a right-based approach to the protection of environment. Since then, it has become recognised that human rights can only be enjoyed in a pollution-free environment. The right to life may be violated by pollution of environment, which could endanger right to property as well, through interference with enjoyment of one's property. This paper explores the various ways through which the right to a healthful environment can be ensured from the perspective of Islam. Although many articles have been written on the perspective of Islam to the protection of environment, very few exist on the rightbased approach to the protection. This paper examines the issue from the perspective of the five major principles of Sharî́ah popularly referred to as Maqâsid Sharî́ah.
\end{abstract}

* LLM, BL, LLB, Lecturer, Department of Public Law, Faculty of Law, University of Ilorin, Nigeria. PhD Candidate, Ahmad Ibrahim Kulliyyah of Laws, International Islamic University, Malaysia. E-mail: barristeraba01@yahoo.com. 
Keywords: Maqâsîd, Sharî‘ah, Life, Property, Intellect, Future Generation, Healthful Environment.

\title{
SATU KAJIAN MENDEDAHKAN PENDEKATAN ISLAM DALAM JURISPRUDENS HAK KEPADA ALAM SEKELILING YANG MENYIHATKAN
}

\begin{abstract}
ABSTRAK
Persidangan Stockholm 1972 adalah titik tolak kemunculan pendekatan berasaskan hak kepada perlindungan alam sekeliling. Sejak itu, masyarakat antarabangsa mengiktiraf bahawa hak asasi manusia hanya boleh dinikmati dalam alam sekeliling yang bebas pencemaran. Hak kepada kehidupan dicabuli oleh pencemaran alam sekeliling, yang boleh membahayakan hak kepada harta juga, melalui gangguan terhadap penikmatan harta seseorang. Makalah ini menjelajah pelbagai cara di mana hak kepada alam sekeliling yang menyihatkan boleh dipastikan dari perspektif Islam. Walaupun banyak makalah telah ditulis tentang perspektif Islam mengenai perlindungan alam sekeliling, hanya sedikit yang telah ditulis tentang pendekatan berasaskan hak kepada perlindungan. Makalah ini meneliti isu ini dari perspektif lima prinsip utama Syariah yang lebih popular dirujuk sebagai Maqasid Syariah.
\end{abstract}

Kata kunci: Maqasid, Syariah, kehidupan, harta, daya fikir, generasi masa depan, alam sekeliling yang menyihatkan.

\section{INTRODUCTION}

The term "environment" as well as its' synonym "surroundings," symbolizes all situations, conditions and circumstances that has an effect 
on the growth of a living being. ${ }^{1}$ It predominantly includes all living things like human beings, animals and plants and non-living things, i.e. soil, water, light, climate, temperature etc. that exist on our planet. Environment occupies an innermost place in most of the deliberations of development strategies in the contemporary globalised world. ${ }^{2}$ This is because deteriorating environment negatively affects human lives and is an impending danger for future generations. Thus the vital question of human survival on an environmentally fragile planet has gained urgency. ${ }^{3}$ There

$1 \quad$ See D. Shelton and K. Alexander, Judicial Handbook on Environmental Law, UNEP, 2005, 3-4; Hannum, H., "New Developments in Indigenous Rights,” (1988) 18 VA J. INT’L.L 649, 666. See M. Gruter, “The Origins of Legal Behavior," (1979) J. Social Biol. Struct.43; Christopher Stone, "Should Trees Have Standing? Towards Legal Rights for Natural Objects,” (1974) 45 S.CAL. L.REV; Christopher Stone, "Should Trees Have Standing Revisited: How Far Will Law and Morals Reach? A Pluralist Perspective,” (1985). 59 S.CAL L. REV.1 both cited in Dinah Shelton and Alexander Kiss, International Environmental Law, $3^{\text {rd }}$ ed., Transnational Publisher, USA, 12.

2 J. Buck Cox, "No tragedy on the Commons" (1985) 7 Environmental Ethics, 49-61; J.W. Futrell, "The History of Environmental Law" in C. Cambell-Mohn, B. Breen and J.W. Futrell (ed.), Environmental Law from Resources to Recovery, St. Paul, Minn., West Publishing, 1993; Grieder T., "Landscapes, the Social Construction of Nature and the Environment” (1994) 59 Rural Sociology, 1.

3 UNEP's Global Environment Outlook Year Book 2003 highlights the scope and variety of the problems. Over one billion people currently lack safe drinking water and sanitation, making waterborne diseases one of the leading causes of death, especially among children in poor countries. Two-thirds of the world's population now lives in areas of water shortages where, increasingly, desertification threatens the food supply. UN Habitat 2003 reported that more than 180 million people in Africa live in fragile areas where they compete for water and land. In marine waters, nearly three-quarters of all commercial fish stocks are being harvested faster than they can reproduce (FAO, 2002). More than 500,000 people in Asia die every year from diseases related to air pollution (WHO, 2003). Species are becoming extinct at an unprecedented rate, taking with them potential yet unknown sources of medicines, nutrition and other benefits. Munich Re, the world's largest reinsurance company, predicted in 2003 that the global economic loss due to extreme weather events would reach US\$30 billion annually 
is increasing anxiety about the environmental problem throughout the world. In the West, a novel subject called 'Environmental Economics' has emerged to study the different dimensions of this problem. ${ }^{4}$ Despite such efforts, the problem of environment has been worsening. The environmental economists were neither able to adequately address the problem nor proffer tangible solutions due to their limited vision. ${ }^{5}$ However, Islam with its broad and divine vision can suitably diagnose the problem and propose successful solutions. ${ }^{6}$ It is on this premise that this paper examines the perspective of Islam on the protection and realization of the right to a healthful environment. The paper begins by examining the relationship between man and the environment from the Islamic perspective. This involves an analysis of the responsibility of men to God in their relationship and dealings with the natural environment. It also examines the various principles in Islam, which can be invoked in the protection of the environment. This is done through the five major objectives of Sharî ${ }^{c} a h$. These objectives show the link between human rights and the environment from the Islamic perspective. The paper places heavy reliance on the two major sources of Sharî́ah i.e. Qur'an and Sunnah. Apart from the primary sources, writings of modern scholars on the issue are referred to in the evaluation of the Islamic perspective in this respect.

by 2050. In sum, humans are rapidly exceeding the carrying capacity of the environment. The information was retrieved from http:// www.unep.org/yearbook/2009/ [accessed on 22/09/2011]. Institute of Islamic Thought and Islamic Research Institute, 1993; P.R.P. Coelho, and J.E. Mcclure, “Towards an Economic Theory of Fashion” (1993) Economic Inquiry, Vol. XXXI.

Ibid.

Abubakar Ahmad Bakadar et al, "Islamic Principles on the Conservation of the Environment," in Islam and Environment, ed. A.G Agwan, New Delhi: Institute of Objective Studies, 1997, 71-107; Khalid Mahmud 'Abdullatif, al-Bi'ah wa al-Talawwuth: Min Manzar al-Islam, Cairo: Dar al-Sahwah li al-Nashr, 1993; Muhammad 'Abdul Qadir al-Faqi, alBi'ah: Mashakiluha wa Himiyatiha min al-Talawwuth (Ru'yah Islamiyyah) Cairo: Maktabah Ibn Sina, 1993; S.K. Hamarneh, Background of Yunani Arabic and Islamic Medicine and Pharmacy, Karachi, Hamdard Foundation, 1997, 71-72. 


\section{ISLAM AND THE PROTECTION OF ENVIRONMENT}

To understand how important environment is in Islam, we need to understand the meaning of Islam itself. Islam to some is understood to mean religious practices that regulate the relationship between people and their creator. In the actual sense, Islam goes further than that. It does not only regulate man's affairs with his creator, but also governs the relationship between creatures as well be they Muslim or not. Islam sees everybody to be living by the will of Allah and thus is obliged to carry out all his wishes so long as he or she remains on earth. In essence, Islam is a total way of life. Islam is a religion that discusses all aspects a human being could ever think of, and also has an answer to it. This is because the activities of humankind are subject to the dictate of Allah (s.w.t) since he has total dominion over man's life and death. This is not only in environmental issues. Islam also offers certain predictions relating to humankind, their civilization and the future. This is acknowledged not only by Muslims, but also by others who had researched into Islam and understood its detailed guidelines. Islam attaches considerable importance to preservation and protection of the quality of natural environment.

One of the contentious issues facing the human communities and also the entire universe relates to environmental challenges. In fact, it has negative consequences on the health of persons and society. It is usually argued that environmental crisis is primarily due to the unsustainable use of resources brought about by the development of science and technology. It has however been posited that world religions are the basis of problems affecting our environment. Lynn White posited that world religions are the source of environmental problems. ${ }^{7} \mathrm{He}$ argued that what people think about their ecosystem is dictated by what they think about themselves in relation to things around them. Human ecosystem according to him is deeply accustomed by beliefs about our environment and destiny, that is, by religion. This means that the attitude of the people towards the ecological units is dictated by their religious teachings and practices. ${ }^{8}$ Thus, this simply supports the fact that religions

\footnotetext{
$7 \quad$ Lynn White "The Historical Roots of our Ecological Crisis” retrieved from http://www.zbi.ee/ kalevi/lwhite.htm [accessed on the 15th January, 2012].

$8 \quad$ Ibid.
} 
especially Islam cannot be disassociated from our dealings with the natural environment. ${ }^{9}$ Ahsan rightly opined that 'it emerges from the Quranic account that the human being had its beginning in an environment full of vegetation, and the first knowledge given to him was also related to a plant. $^{10}$

It must be acknowledged the fact that a lot of ecological units or species are running within the territory of the environment. ${ }^{11}$ These numerous species rely on natural environment to survive. ${ }^{12}$ Without the environmental segments, the living creatures cannot sustain themselves and they may eventually perish. ${ }^{13}$ The Islamic perception on the environment rests on the belief that Allah (s.w.t) is the architect and Sustainer of the creation. He has created the whole world and its supportive components with perfect wisdom (hikmah). The use and other activities related to these components have been specifically defined in a divine manner. Allah has a spiritual purpose behind the creation of everything and such purpose must be taken with seriousness and be accomplished. This is confirmed in the Holy Qur'an as follows:

"We did not create the heavens and the earth and what is between them except with justice and for a specified term. However, those who disbelieve, from that of which they are warned, are turning away."14

Ibid.

10 Ahsan, Muhammad, Contribution of Medieval Muslims in the Field of Agricultural Research and Development (Urdu). Rawalpindi, Foundation for Research on International Environment, National Development and Security, 2000 quoted in Mumtaz Akhtar, "Islamic Educational Approach to Environmental Protection: A Strategic Approach for Secure and Peaceful World” (2010), Vol. 1, No. 3, (December), International Journal of Business and Social and Science, 182-191.

11 S. H. Nasr, "Islam and the Environmental Crisis," MAAS Journal of Islamic Science Vol. 6, No. 2 (July-December, 1990), repr. In Islam and the Environment, (Agwan A.R ed.), New Delhi: Institute of Objective Studies, 1997, 31.

12 Ibid.

13 Ibid.

14 See Qur'an 46: 3. In other words, this suggests that if the temporal authorities view their own words and resolutions to be right and those 
This verse portrays the need to ensure the continuity of the environmental components and maintain a balance. Consequently, environment is viewed in Islam from the perspective of balance. ${ }^{15}$ This is further corroborated in the following ayah:

"And the earth, We have spread it and cast therein firmly set mountains, and caused to grow therein something of every well-balanced thing. And We have made for you therein means of living, and for those for whom you are not providers." 16

The above verse is of fundamental importance. It reflects a clear manifestation of the need to maintain equilibrium or balance in everything. Therefore, we must uphold the balance of the nature in our dealings with the environment. The verse reveals that all kinds of provisions have been made available for the survival of humanity and non-human species. This suggests that we have the right to use the available resources to meet our needs but at the same time, we must assure balance so that the natural environment will not be adversely affected. The issue of relative shortage or surplus does not therefore arise in the divine map regulating the use of these resources. The phrase balance insinuates two limitations. The first is that we should not exploit the natural ecosystem beyond its competent capacity. The second is that we should minimize the magnitude of the waste products discharged into the environment to a level where the system is capable of recycling them without altering its output

given by God as erroneous they are disbelievers. If on the other hand they regard God's instructions as right but knowingly refuse them and implement their own decisions against God's, then they are the mischiefmakers and the wrongdoers. Fasiq, the law-breaker, is the one who disregards the bond of faithfulness, and zalim is he who works against the certainty. Thus all those temporal authorities who claim to be Muslims and yet defy the rights sanctioned by God belong to one of these two groups, either they are the disbelievers or are the wrongdoers and mischief-makers. Environmental Balance” (1996), Vol. 3, No. 2, Islamic Economic Studies, 58-76.

16 Qur'an 15: 19-20. 
capacity. ${ }^{17}$ The environment tends to face challenges due to the contravention of these constraints. In other words, the unjustifiable use of natural resources coupled with the indiscriminate discharge of waste products is the root cause of environmental problems. Therefore, the Islamic approach presents a suitable mechanism aimed at solving these problems. It does this through a mechanism ensuring equilibrium that seeks to strikes a balance between human needs and the protection of the environment. ${ }^{18}$

\section{ENVIRONMENTAL PROTECTION PRINCIPLES}

In Islam, environmental principles can best be understood and appreciated from the perspective of the objectives of Sharî́ $a h$, i.e. the purposes of Sharî ${ }^{c} a h$, that constitute the general objectives that Islam has come to serve. These objectives are usually categorized into five, commonly referred to as Maqâsid Sharî́ah. They are: protection of religion, protection of life, protection of properties, protection of human race, and protection of human intellect.

\section{(i) Protection of Religion}

The first and foremost objective of Shari ${ }^{c} a h$ is to preserve and protect the religion itself. It is fundamental that every society must put in place rules and regulation to govern their affairs. It is impossible to survive without rules requiring compliance. Otherwise, the magnitude of transgression will be alarming. If laws or rules are so vital to the human

$17 \quad$ Usmani, Shabbir Ahmad, Tafseer-e-Usmani, Karachi, Dar-ul-Tasneef, 689; Beloch Sehryani, Abdul Khaliq, The Concept of Regional Rights in An Islamic State, Jacobabad: Maktaba Islah-e-Milat, 1989.

18 Chapra, M. Umar, Islam and Economic Development, International Institute of Islamic Thought and Islamic Research Institute, 1993; Husaini, S.W. Ahmad, Islamic Environmental Systems Engineering: A Systems Study of Environmental Engineering, and the Law, Politics, Education, Economics, and Sociology of Science and Culture of Islam, London: Macmillan Press, 1980, 1-15, 144-145. 
existence, then religion is the mother of all rules and law in the universe. It is in the light of this that Allah has sent his revelation to humankind for guidance and set the limits to regulate our interactions. Thus, to protect Islam as a religion, one must first believe in the revelation and messages of Allah. This belief is succinctly referred to as al-Tawhid. Tawhid is part of the religion and the beginning of the Islamic faith. Allah says of Himself in the Qur'an:

"And to Him belongs whoever is in the heavens and the earth. All are to Him devoutly obedient. And it is He who begins creation; to Him belongs the highest description in the heavens and the earth. And He is Exalted in Might, and Wise.”19

The above verse stresses in the unity of Allah; That is, the belief that the entire world is created, regulated and maintained by Allah, the Supreme Being. It defines God-man, man-man, and man-universe interactions..$^{20}$ This provides a Muslim with the vision that Man and other living creatures including the environment belong to the same unit and that both are subject to divine regulation. By this, the protection of the environment becomes a religious task. ${ }^{21}$ This perception provides moral and spiritual stimulation for the protection of the environment. It is common knowledge in Islam that when Allah created the first man (Adam), he gave him directions to be followed. It was his action that led to mankind being sent down to the earth. This tells clearly that men do not have the liberty to do whatever they like. The expression ‘Islam’ accurately means obedience or surrender, and a Muslim is one who submits his self-control to the will of God. ${ }^{22}$ The origins of Islamic environmental practice are contained in the Qur'an and the leadership (Sunnah) of Prophet Muhammad.

Above all other monotheistic faiths, Islam as a religion is built on the conviction in the existence of a powerful creator. It has been revealed in the Holy Qur'an that Allah creates the whole universe, and that

\begin{tabular}{ll}
\hline 19 & Qur'an 30: 26-27. \\
20 & Ibid. \\
21 & Ibid. \\
22 & Ibid.
\end{tabular}


orderliness and balance are incorporated in the rules of creation. ${ }^{23}$ The Qur'an Says: "He to whom belongs the dominion of the heavens and the earth.... and has created each thing and determined it with a precise determination." ${ }^{24}$ In another verse, the Qur' an says: "It is He who made the sun a shining light and the moon a derived light....Allah has not created this except in truth. He details the signs for a people who know." ${ }^{25}$ Thus, belief in Allah entails believing in whatever He has created and following the directions pertaining to their use. Therefore, the way and manner in which we are to relate with the resources of the natural environment too are incorporated within the value system of Islam. ${ }^{26}$ The Holy Qur'an confirms this by saying, "We have not neglected in the Register a thing." 27 In this regard, Allah ordered man to follow the dictate of his creator if he truly believed in Him. The Qur'an states that:

"O you who believe, be persistently standing firm in justice, witnesses for Allah, even if it be against yourselves or parents and relatives. Whether one is rich or poor, Allah is worthier than both. So follow not your personal inclination and deviate from the truth. If you refuse, Allah is well acquainted of what you do." ${ }^{28}$

Therefore, tawhid is the foundation of every aspect of the Muslim's life. It lays the basis for every aspects of human life. This is because it is only when a person believes in the oneness of his creator (Allah) that he or she becomes conscious of the dealings with other beings, which include the natural environment. In the light of this, the questions what the purpose of man's creation in this earth is and what his responsibility in this world is are therefore relevant and vital to understand the nature of man relationship with the natural environment. The primary purpose of man on earth is to obey and serve Allah alone. Thus, in accordance with the Qur'anic teachings, man is seen as the

\begin{tabular}{ll}
\hline 23 & Ibid. \\
24 & Qur'an 25: 2. \\
25 & Qur'an 10: 5. \\
26 & Ibid. \\
27 & Qur'an 6: 39. \\
28 & Qur'an 4: 134.
\end{tabular}


trustee or vicegerent of Allah in order to accomplish his duties on earth. ${ }^{29}$ Man is seen as the khalifah in this planet, ${ }^{30}$ that is, a representative of Allah. The prime responsibility of the khalifah is to manage the trust bequeathed to him. ${ }^{31}$ In other words, man has a delegated power on behalf of the Supreme Authority (Allah), ${ }^{32}$ On this note, and man is answerable to Allah in the use and management of the trust. Thus, resources of the earth are to be seen as a trust bequeathed to us for use and to ensure its safety. It is no more a secret that the origin of problems associated with the environment rests on the unacceptable treatment of natural resources. Therefore, the perception of man as a trustee of these resources implies that man will be called upon to account for his dealings with the natural environment in the hereafter. This means that belief in akhirah, that is, 'the day of judgment' in which the trustee would be answerable to Allah will go a long way in shaping our attitude towards the environment. ${ }^{33}$ It should be borne in mind that the Islamic belief in the hereafter should also influence our behavior or attitude towards the environment.

Thus, as khalifah man has a duty to be obedient to Allah and ensure judicious protection of His creation on earth including the environment. ${ }^{34}$ The Prophet (PBUH) has said that 'the world is green and God has appointed you His vicegerent.' Therefore, in Islam, the position of mankind is that of a trustee of property. The only difference in the concept of trustee in the Islamic context is that, the trustee with regard to environment has the right to make use of available resources to satisfy his or her needs in an equitable manner, without jeopardizing

\footnotetext{
29 Qur'an 6: 165, 7: 181, 17: 70.

$30 \quad$ Ibid.

31 Sarvenoz Bahar "The Islamic Republic of Iran, and International Law: The Relevance of Islamic Political Ideology” (1992), 33 HARV. INT'L L. J., 145 .

$32 \quad$ Ibid

33 Mumtaz Akhtar, "Islamic Educational Approach to Environmental Protection: A Strategic Approach for Secure and Peaceful World" (2010), Vol. 1, No. 3, (December), International Journal of Business and Social and Science, 182-191.

$34 \quad$ Liewellyn, Othman Abd al Rahman, "Islamic Jurisprudence and Environmental Planning” (1984), Vol.1, No. 2 (Winter), Journal of Research in Islamic Economics, 25-49.
} 
the interests of other creatures that also depend on the environment for their survival. On this note, the Prophet was reported to have said as narrated by Abu Said al-Khudri that:

\section{"Verily, this planet is lovable and beautiful. Allah had appointed you as vicegerent on this Planet. Thus, He forever observes how you deal with it."35}

In Islam, man's relationship with Allah is similar to that of an employer and an employee. In so far as the employee is desirable of retaining his position, he must always act according to the instruction and dictate of his employer. The employee must be prepared to render account when demanded by the employer. Therefore, in Islam, man is seen as a representative of Allah and his dealings with other creatures must be according to the instructions of Allah. There is unity in creation and humans as representatives should strive to uphold a balance with the natural world.

As a trustee, man is bequeathed with the freedom and latitude to make use of resources on the planet. However, like all trustees, man has a corresponding duty not to misuse or cause damage to them. ${ }^{36}$ This suggests that man, as a trustee of Allah would be required one day to give account of his dealings with the entrusted property. Therefore, the concept of akhirah is closely linked to the concept of Khalifah. Thus, these two key concepts of life should guide man to ensure that the resources of the earth are utilized in a judicious manner. The starting point to embrace this perception is Tawhid.

\section{(ii) Protection of Life}

On the issue of protection of life, many human practices are endangering to human life. Thus, a Muslim is expected to shun activities likely to put the life of his fellow being in danger. ${ }^{37}$ When it comes to prioritization of

\footnotetext{
35 Al- Qushayri, Muslim Bin Hajjaj, Sahih Muslim, V. 4, 2098, hadith No: 2742.

36 Qur'an16: 12.

37 Abdullahi Ahmed An-Na'im, Toward an Islamic Reformation: Civil Liberties, Human Rights and International Law, Syracuse, NY:
} 
Maqâsid Sharîcah, protection of life takes precedence over protection of property. Hence, a person is not expected to use his or her property in a way that endangers human life. Islam sees life as the entirety of humankind and that is why it is stated in the Qur'an that whoever kills a life is as if he has killed the whole humanity and whoever saves a life will be rewarded as if he has saved the entire human race. ${ }^{38}$ Therefore, if we do anything that will endanger a single life through our action or inaction, we are seriously violating the second objective of Sharî́cah, which is the protection of life. ${ }^{39}$

In Islam, it is forbidden to kill a life unlawfully without a just cause. Islam did not only prohibit taking a life unlawfully, it also forbids causing harm to another person. Stressing the sacredness of life, Allah says in the Holy Qur'an:

\begin{abstract}
"And do not kill a soul which Allah has forbidden, except for a right. And whosoever is killed unjustly, We have given his heir authority, but let him not exceed limits in the matter of taking life. Indeed, he has been supported by the law." 40
\end{abstract}

The above verse portrays that killing a person without a justifiable reason is prohibited by Allah and any one that violates such injunction, a great punishment awaits him or her. ${ }^{41}$ This verse deals with causing death and as such, it may be of little assistance in appreciating environmental protection in the context of protecting life. However, in some other verses of the Holy Qur'an, Allah has enjoined us to desist from activities likely to endanger or cause destruction to ourselves, where he has exhorted us to spend in his cause, and do good deeds. ${ }^{42}$ The Qur'an says:

Syracuse University Press, 1990, 185. T. Lindholm, The Cross-Cultural Legitimacy of Human Rights, Oslo: The Norwegian Institute of Human Rights, 1990; William Montgomery Watt, Islamic Fundamentalism and Modernity, London: Routledge, 1988; M. Youssef Choueiri, Islamic Fundamentalism, Boston: Twayne Publishers, 1990.

See Qur'an 5: 32.

Ibid.

See Qur'an 17: 33.

See Qur'an 5: 32.

See Qur’an 2: 192. 
"And spend in the way of Allah and do not throw yourselves with your own hands into destruction. And do good; indeed Allah loves the doers of good.”

It is now widely acknowledged that environmental pollution endangers human life and survival. The protection of human life depends on our relationship with the nature and the environment. It can therefore be argued on this premise that erroneous treatment of the natural environment and the ecosystem is an act that could lead to destruction. Most of the challenges associated with the natural environment are due to the inability of humans to restrain themselves in the use of those resources. Environmental damage falls under categories of activities likely to cause destruction to man's life. Thus, a Muslim is under religious duty to regulate his dealings with the environment and not to engage it in a way that will cause destruction to life. By this, we will be protecting the natural resources of the earth and safeguard the right to life.

\section{(iii) Protection of Human Intellect}

Some activities affect the reasoning faculty of human beings. Islam has forbidden us from consuming anything that may likely interfere with the functioning of the mental faculty of man. For instance, Islam forbids intake of liquor, alcohol, marijuana, heroin and other similar things capable of negatively influencing man. ${ }^{43}$ Basically, anything whether of food or drink is unlawful if taking it would incapacitate man's intellect. ${ }^{44}$ This kind of prohibition may not tell much in relation to the environment. It therefore requires a deeper understanding and explanation of how what affects the intellect may negatively affect the environment.

We can view human intellect from more than one angle in the protection of the environment. If a Muslim does something that renders his God given intellect impotent, it is more than likely that the person will not only do damage to himself but will do more damage to the environment. For instance, when a person urinates in a pool of water meant for the whole community, such a person has not made use of his intellect positively.

\begin{tabular}{ll}
\hline 43 & See Qur'an 5: 90. \\
44 & Ibid.
\end{tabular}


Thus, it requires the potency of human intellect to guide against environmental devastation. Most of the challenges associated with the environment are due to the perception of man's superiority over other beings. Thus, it requires good intellect to appreciate that other creatures too have been created by Allah for a purpose and such propose must be fulfilled by man if our basis of existence is to serve Allah. So man must at all times apply his intellect positively to ensure that the rights of others are not violated and avoid damage to the ecosystem and resources.

Another angle of human intellect is the practice of good neighborliness, that is, caring for fellow human beings. No one is truly a believer in Islam until he desires for his fellow being what he desires for himself. The necessity of the time demands that the said principle be applied to the protection of environment. Having a feeling for fellow beings whether Muslim or not is an essential part of brotherhood in Islam. This brotherhood is manifested in the practice of the Holy Prophet (PBUH), as illustrated in the following sayings of the Prophet:

(a) Muslims are brothers to one another. Do no wrong yourselves or abandon another Muslim without help. ${ }^{45}$

(b) I swear by Allah, no one is truly a Muslim except that he wishes for others whatever he wishes for himself. ${ }^{46}$

The aforesaid traditions of the Prophet exhort Muslims to love and cooperate with one another and to desist from activities likely to injure or harm others. Thus, if a person desires a healthy and pollution free environment for himself, he must not carry out activities likely to prevent his neighbors from enjoying a healthy environment as well. The Prophet (PBUH) in Medina encouraged the principle of brotherhood, which united the immigrant and local families together, both sharing a common pool of resources. This suggests that the religion of Islam propagates caring for one another. This principle supports the no-harm rule widely acknowledged internationally. Furthermore, this would create environmental consciousness in our dealing with natural resources. 


\section{(iv) Protection of Human Race}

This is the fourth objective of Sharî́ah. It has been decreed by Allah that the human race will continue to be in existence until the day of resurrection. This signifies the reason why Islam forbids anything that can lead to the extinction of the human race. It is the objective of the Shari ${ }^{c} a h$ to ensure the continuity of the existence of human beings on earth and humankind must not do anything to the contrary. Thus, the resources of the earth mst not be used in a way that affects the chance of future generations to have access to the same resources for meeting their own needs. This means that the interest of the future generations must be borne in mind in our dealings with the natural environment.

During the life of Umar (RTA), "ganima" (booty gained in a battle) came into the possession of Muslims. The expectation originally was that it would be distributed among whoever participated in acquiring them. To the surprise of Muslims, Umar said that he had read a verse in the Qur'an that referred in clear terms to Muslims being categorized into three. ${ }^{47}$ The first and the second are the sabikun i.e. those who have gone before ${ }^{48}$ and the current generation, and the third is the coming generation, i.e. those yet to be born. ${ }^{49}$

Therefore, as Muslims, we owe a duty to the coming generation. As such, the resources of the earth must not be exhausted for fulfilling the needs of the present generation. If by our actions and our dealing with the environment, the interests of the coming generation are being jeopardized, then we are actually failing in our responsibility towards them. Thus, we must not do anything that will make life unbearable for the coming generation, which forms a major part of our duty with regard to the environment.

It has earlier been argued in this paper that the position of man before Allah is that of a trustee over the resources of the planet. If that is the case, then man must safeguard the trust not only for his benefit but also for the benefit of his successors, i.e. the coming generations. The Holy Qur'an acknowledges this fact when it says, "We have made for you therein means of living and for those for whom you are not providers."

\begin{tabular}{ll}
\hline 47 & See Qur'an 59: 7-19. \\
48 & Ibid. \\
49 & Ibid.
\end{tabular}


This verse implies that Allah has provided for the every generation means of livelihood. Based on this, a Muslim is under obligation not to misuse the resources allocated in the interest of others, among whom are the generations to come.

\section{(v) Protection of the Property}

The right to benefit from the vital environmental resources such as water, land, forest, minerals, air and others is assured in Islam. Humankind has been given the latitude to use the resources of the earth to their advantage based on their needs, while bearing in minds the potential effect on the environment and its degree. ${ }^{50}$ The Islamic nation has been labeled as the moderate nation (ummatan wasatan) as stated in the Qur'an, one that avoids excesses in all things. Thus, Muslims in particular have to utilize the earth sensibly for their advantage, maintain and preserve it truthfully, use it caringly and moderately, and pass it on to future generations in an admirable condition. ${ }^{51}$ This includes appreciation of its beauty and use according to the instructions of Allah. ${ }^{52}$

The exploitation of all natural resources such as water, air, land, forests and other useful elements are considered as a common right of the universe. Thus, we must not violate the rights of others in the use of those resources. A safety measure is thus required by man to make sure that the interest of others are not disregarded in the use of his property. ${ }^{53}$ Prophet Muhammad is reported to have said, "Whosoever brings dead land to life, for him is a reward, and whenever any living thing seeking food eats of it, it shall be reckoned as charity from him." 54 In another narration, the Prophet said, "Where a person plants a tree, and humans

\footnotetext{
$50 \quad$ Ibid.

$51 \quad$ Mamtaz Akhtar, "Islamic Educational Approach to Environmental Protection: A Strategic Approach for Secure and Peaceful World” (2010) Vol. 1, No. 3 (December), International Journal of Business and Social Sciences, 182-191.

$52 \quad$ Ibid.

$53 \quad$ Fazul M. Khalid, “Islam and the Environment” (2002), Vol. 5, Social and Economic Dimensions of Global Environmental Change, 332339.

$54 \quad$ Abu Dawud, V. 3, 178, hadith No: 3074.
} 
or any other creation of Allah eat from it, it shall be reckoned as charity from him." 55 This saying of the Prophet is a testimony to the fact that resources of the earth are meant to be exploited subject to limitations prescribed by Allah.

It is also notable in this regard that Islam has forbidden the destruction of property during wartime. The companions of the Prophet (peace be upon them) emulated this in order to conserve the environment. Abu Bakr ordered his general, Yazid ibn Abi Sufyan, to observe firmly the environmental values even in the enemy territory. He wrote:

"Do not cut down a tree, do not pollute a river, do not harm crops and animals, and always be kind and humane to Allah's creation, even your enemies." 56

This instruction mirrors the level of importance attached to property in wartime. The war must be engaged in judiciously. Islam categorically forbids the destruction of properties of the enemy during war so far as it is not the focus of the war. Hence, war must be carried out in a way that does not endanger the environment. This shows that Islam does not ignore the sensitive nature of the ecosystem. Another aspect concerning the protection of property that deserves explanation is the position of Islam on wastage of resources. The fact that Allah has produced resources in abundance does not confer legitimacy to misusing it and in wasteful conduct contrary to the dictate of Allah. The Holy Qur'an says:

"And He it is who causes gardens to grow, both trellised and untrellised, and palm trees and crops of different kinds of food and olives and pomegranates, similar and dissimilar; eat of each of its fruit when it yields and give its due on the day of its harvest. And be not excessive. Indeed, He does not like those who commit excess." 57

\footnotetext{
55 Al-Bukhary, V. 2, 817, hadith No: 2195, Muslim, V. 3, 1189, hadith No: 1553.

56 Malik Bin Anas, Abu Abd Allah, Muwata Malik, Ed. V. 2, 447 hadith No: 965.

57 Qur'an 6: 141.
} 
In another verse, Allah Says: "eat and drink, but be not excessive. Indeed, He likes not those who commit excess." ${ }^{58}$ These verses absolutely ban wastage in the use of resources. Thus, the quantities of such resources do not determine the degree of use. The Qur'an and Sunnah underscore the need to conserve both the quality and quantity of these resources. For example, water is regarded as a fundamental source of life. The Prophet during his lifetime specifically and expressly emphasized the preservation of water. He has enjoined Muslims to use a reduced amount of water even at a flowing stream. He also forbade urination in water and in animals' waterholes. This prohibition in fact symbolizes Islam's concern regarding the degradation of environment and means of protecting the resources in the planet. A companion of the Prophet named Sa'd was one day performing ablution for prayer at a stream and the Prophet, peace be upon him, noticing that he was using too much water asked:

"What is this wastage, O Sa'd? Sa'd replied: Is there wastage even in washing for prayer? The Prophet peace be upon him replied: Yes even when you are by a flowing river." 59

Thus, the lawfulness of an action and abundance of a natural resource is no justification for engaging in wastage. It can therefore be concluded that the protection of property is multifarious from the Islamic point of view. First, it gives an individual the right to make use and enjoy his property. The limitation to this is that such right should not be used in a way that jeopardizes the quality of the environment or the rights of others. Secondly, it has instructed humanity to be just in their dealing with the ecosystem and its resources in order to maintain a balance in the structure that sustains the planet. Lastly, it condemns waste of resources and warns that Allah dislikes those that engage in wastefulness. In this manner, the environmental elements that sustain generations of humans are sought to be protected. This is so because when environmental damage occurs, it usually affects the elements of the environment.

\footnotetext{
$58 \quad$ Qur'an 7: 31.

59 Sunan Ibn Majah, V. 1, 147, hadith No: 425, Ahmad, V. 2, 221 hadith No: 7065.
} 


\section{CONCLUSION}

It must be acknowledged that there is a fundamental dichotomy in reality between the Islamic concept of environmental protection and environmental issues as perceived conventionally. While in Islam man is seen as the representative of Allah and as such having a religious duty to safeguard nature and expected to give account of his or her stewardship on the day of akhirah, the conventional principles are guided by rules formulated at international or domestic level. Thus, if the true purpose of man is to worship Allah he must abide by the do's and do not's of his creator, and ensure obedience to his instructions with regard to the protection of environment. Obedience to the will of Allah as discussed in the paper will go a long way in enhancing and promoting the right to a healthful environment. 